\title{
Balıkların Önemli Viral Hastalıkları
}

\author{
Ali Küçük ${ }^{1}$, Yakup Yıldırım ${ }^{1}$ \\ Mehmet Akif Ersoy Üniversitesi, Veteriner Fakültesi, Viroloji Anabilim Dal, Burdur \\ Geliş Tarihi / Received: 15.08.2016, Kabul Tarihi / Accepted: 18.12.2016
}

\begin{abstract}
Özet: Dünya var olduğundan beri insan, çevresinde bulunan besin maddelerinden yararlanmayı amaçlamıştır. Bu doğrultuda su ürünleri, özellikle balıklar besin kaynağı olarak kullanılmıştır. Gerek avcılıktan gerekse yetiştiricilikten elde edilen bu ürünler insan tüketimine sunulmaktadır. Bu ihtiyaçtan doğan sektörün günbegün büyümesi su ürünleri üretimini veya avcılığını olumsuz yönde etkileyen, verimini düşüren ve üretimde istikrarsız bir tablo oluşturulmasına sebep olan olguların bilimsel yönden araştırılması zorunluluğunu ortaya çıkarmıştır. Bu olumsuzlukların en önemli sebeplerinden biri olarak kabul edilen viral hastalıklar, dünya sularındaki balıklarda yüksek mortalite ve morbidite oranı ile sektöre büyük bir darbe vurmaktadır. Bu derlemenin amacı, yetiştiriciliği veya avcılığı yapılarak tüketime sunulan balıkların viral hastalıkları hakkında bilgi vermektir.
\end{abstract}

Anahtar kelimeler: Balık, viral infeksiyon

\section{Important Viral Diseases of Fish}

\begin{abstract}
Ever since the world begun, human have aimed to nutrients around. Accordingly, fisheries, especially fish, have been used as a nutritional source. These products either by hunting or breeding are offered for human consumption. Day by day growing of this sector from necessity is provided the scientific need to search the facts affecting the breeding or hunting of water products, decreasing its productivity and causing an unsteady statement in production. Viral diseases are one of the most important reasons for these negations deal a major blow in the sector with high mortality and morbidity rates for all fish in world waters. The purpose of this review is to provide information about viral diseases of fish offered for consumption by means of breeding or hunting.
\end{abstract}

Key words: Fish, viral infection

\section{Giriş}

Yaklaş1k \%71'lik bölümünün sulak alanlarla kaplı olan yerkürede sayıları ve ekosistemdeki işlevleri tespit edilememiş sucul milyonlarca canlı türü yaşamaktadır. İnsanlar tarih boyunca başta balıklar olmak üzere diğer su canlılarından besin kaynağ 1 olarak yararlanmışlardır. Bu sebeple, dünya ülkeleri imkanları dahilinde ellerinde bulunan su varlıklarını olabilecek en akılcı biçimde kullanmaya hatta mevcut su varlığını azami seviyeye çıkarmanın çabasını göstermişlerdir [61].

Toplam üretimi 2012 yılında yaklaşık 158 milyon ton, 2013 yıllında ise yaklaşık 163 milyon tona ulaşan dünyadaki balık üretiminin büyük çoğunluğunu: Çin, Hindistan, Endonezya ve Amerika Birleşik Devletleri tarafından yapılmaktadır. En son verilerde Çin'in Dünya balık üretimindeki \%37.2 olan payının \%71'nin kültür balıkçılığından karş1ladığı açıklanmıştır. Diğer ülkelerin payları ise s1rasıla Hindistan \%5.8, Endonezya \%5.6, Amerika
Birleşik Devletleri \%3.5 ve AB ülkeleri \%3.7'dir. Kalan payı ise diğer dünya ülkeleri üretmektedir [16].

Bu derlemenin amac1, yetiştiriciliği veya avc1lığı yapılarak tüketime sunulan balıkların viral hastalıkları hakkında bilgi vermektir.

\section{Balıkların Viral Hastalıkları}

\section{Infeksiyöz Pankreatik Nekrozis (IPN)}

İlk olarak Amerika'da görülen [15] infeksiyöz pankreatik nekrozisin (IPN) etkeni Birnaviridae familyasının Aquabirnavirus genusuna ait Enfeksiyöz Pankreatik Nekrozis Virustur (IPNV) [19]. Etken, UV' ye karşı dirençli olmasına karşın, klorin ve iodin ile inaktive olur, alkali pH'a duyarlı iken asidik pH'ya az da olsa dirençlidir [32]. Horizontal ve vertikal yollar ile bulaşan etken genellikle salmon balık yetiştiriciliğinin yapıldığ 1 yerlerde gözlenmektedir. Latent enfekte balıklar enfeksiyonu uzun 
süreler boyunca idrar ve dişkı ile yayabilirler [15]. Birnavirus, sayısız sucul canliyı enfekte etmektedir, Reno (1999) tarafindan sucul canlılar için en yaygin patojen olarak bildirilmiştir. Türkiye'de ilk kez 2002 yılında rapor edilen etken gökkuşağı alabalığı yetiștiriciliğini 1990'dan bu yana büyük ölçüde etkilenmiş ve yavrularda yüksek mortalite ile seyretmiştir [10, 62].

Enfeksiyonun inkubasyon süresi gökkuşağ 1 alabalığ1 ve dere alabalığ 1 yavrularında 4-7 gün iken, Atlantik somon yavrularında 10-14 gündür ve yavrularda \% 90'a varan bir mortalite oranı rapor edilmiştir [62]. Klinik olarak dış bakıda; renkte kararma, abdomende şişkinlik, zig-zag çizerek yüzme gibi semptomlar gözlenir [28]. Bunun dışında, pseudofeçes, eksophtalmus, kafa bölgesinde ufak şişlikler gözlenebilmektedir [32]. Histopatolojik muayenede; bağırsaklarda patolojik bozukluklara rastlanırken, klinik enfekte balıklarda kataral enterite de rastlanmaktadır. IPNV aynı zamanda salg1 üreten dokularda yang1 ve nekrozla bütünleşmiş pankreatite yol açar. Böbrek ve karaciğer bu enfeksiyondan çok fazla etkilenmemesine karşın gastrointestinal sistem yoğun şekilde etkilenir [32].

Polivalan bir anti-IPN virus serumu kullan1larak yapılan serum nötralizasyon testi ile hücre kültüründe izolasyon ve identifikasyonu gerçekleştirilebilen [40] etkenden korunmanın yolu enfekte yada enfekte olduğu düşünülen balık yumurtalarını almak yerine sertifikalı yumurtaların alınması, kaynak sularında üretim yapılması ve enfekte kuluçkahanelerin kapatılmasıdır [32].

\section{Enfeksiyöz Hematopoetik Nekrozis (IHN)}

İlk olarak Kuzey Amerika' da rastlanılan etken, daha sonra Avrupa ve Asya'ya sıçramıştır. WAHIDOİE verilerine göre hastalığa 9 ülkede (Avusturya, Çin, Çek Cumhuriyeti, Almanya, İtalya, Japonya, Hollanda, Polonya, Slovenya) yetiştiriciliği yapılan balıklarda, 2 ülkede (Fransa, ABD) hem vahşi hem yetiştiriciliği yapılan balıklarda, 1 ülkede de (Kanada) sadece vahşi ortamdaki balıklarda rastlanıldığı rapor edilmiştir. Türkiye'de yapılan eski çalışmalarda ise virusun yetiştiriciliği yapılan balıklarda görüldüğü saptanmıştır [14]. Rhabdoviridae familyasıdaki Novirhabdovirus genusu içerisinde yer alan etken [48], asit, eter ve 1sıya duyarlidır. $4^{\circ} \mathrm{C}-20^{\circ} \mathrm{C}$ 'de replikasyon yapabilen virusun opti- mum replikasyon sıcaklığ $15^{\circ} \mathrm{C}^{\prime}$ dir [32]. Birincil olarak horizontal yolla bulaşan hastalık, infekte yumurta, kanemici parazitler, balıkçıl kuşlar, kontamine çiftlik aletleri, solungaç, dışkı ve idrar ile yayılır [32].

IHN salmon ve alabalık yetiştiriciliğinde büyük ekonomik kayıplara yol açar, tatlı su yetiştiriciliğinden daha çok denizde yetiștirilen salmon ve alabalıklar üzerinde deniz suyunun tuzluluk oranından kaynaklanan, ozmatik basınçtan dolayı yüksek mortaliteye sebep olan enfeksiyonlara sebep olmaktadır [28]. $15^{\circ} \mathrm{C}^{\prime}$ nin altındaki sular IHN'nin ortaya çıkması için uygun sıcaklıktaki sulardır. Hastalığ 1 atlatan alabalıklar, herpesvirus enfeksiyonlarında olduğu gibi yaşamları boyunca latent enfekte olarak kalırlar [2].

Virus kapillar damar hücrelerine, haematopoetik organ/dokulara ve nefronlara yerleşir. Virusun replike olduğu dokularda, klinik olarak, hemoraji ve ödem göze çarpar. Erişkin balıkların dirençli oldukları enfeksiyona, genç balıklar daha duyarlıdır [28] Omurgada deformasyona yol açan hastalık, visceral organlarda anemi, gastrointestinal sistemde mukus benzeri s1v1 birikimine sebep olur [32].IHN, Tarım ve Köy İşleri Bakanlığı'nın yayımlamış olduğu 1 Nisan 2004 tarihli 2004/14 sayılı tebliğinden beri ihbarı zorunlu hastalık olarak kabul edilmiştir [29]. Ayrıca, "Avrupa Birliği ülkelerindeki işletmelerde tespit edilebilen, önemli maddi kayıplara yol açan, tedavi ve aşısı bulunmayan ve belirlenen çiftliklerin tespiti zorunlu hastalıklar" listesinde yer alır [52].

Nötralizasyon tekniği ve hematopoetik dokulardaki değişikliklerin saptanmasıyla ayırt edilebilen virustan korunmak için yumurtalar iodofor ile dezenfekte edilmeli, virusun tespit edildiği kaynaklar imha edilmeli ve hastalıkla enfekte olan çiftlikler veya kuluçkahaneler terk edilmelidir [32].

\section{Viral Hemorajik Septisemi (VHS)}

Gökkuşağı alabalıklarının en önemli viral hastalıklarından biri olan VHS' nin [45] etkeni Rhabdoviridae familyasinda bulunan Novirhabdovirustur [28]. 4 farklı genotipe sahip olan etken [45] eter, gliserol, kloroform, formalin, sodyum hipoklorit, UV ışınları ve $56^{\circ} \mathrm{C}-60^{\circ} \mathrm{C}$ de inaktive olur [32]. VHS, Kuzey Yarımkürede'ki pek çok bölgede bulunan tatlı su ve deniz balıklarını enfekte eden sucul bir patojendir $[22,56]$. Viral hemorojik septisemi, OİE' nin 2010 
yılında yayımlamış olduğu listede bildirilmesi gereken dokuz balık hastalığından biridir ve hastal1ğa ilk kez 1949 yılında Danimarka'da rastlanmıştır $[27,60]$.

VHS virusunun taşıyıcıları, klinik veya subklinik infekte kültür yada doğal balıklardır. Etken genellikle idrarla yayılır [28]. $4^{\circ} \mathrm{C}-14^{\circ} \mathrm{C}$ arasındaki su sicaklıklarında görülen hastalığın, düşük su sıcaklıklarında $\left(1{ }^{\circ} \mathrm{C}-5^{\circ} \mathrm{C}\right)$ kronik formuna rastlanılabilir. Hastalığın kronik formunun görülmesi halinde toplu ölümlere yol açtığı belirlenmiştir. $15^{\circ} \mathrm{C}-18^{\circ} \mathrm{C}$ arası su sıcaklıkları ise ölüm oranlarını aşağı çekmektedir. Yılın her mevsimi gözlemlenebilen bu hastalığa özellikle su sıcaklıklarının artmaya başladığı ilkbahar aylarında daha fazla rastlanır [23].

VHS genellikle 40 günlük ya da daha büyük olan küçük balık türlerinde görülür [40]. Klinik bulguları arasında yüzgeç diplerinde peteşiler, hemorojiler, çok soluk yüzgeçler, periocular hemrojiler, laterji, anormal bir yüzüş şekli gösterilebilir. Virusun metabolizmadaki ilk hedefi böbrek ve dalak endotelyal hücreleridir ve bu organlar 1-4 gün içinde enfekte olur. Enfeksiyondan hemen sonra bu organlarda nekrosis ve dejenerasyonlara rastlanır. Deneysel enfekste edilen bir balığın karaciğerinde 4-7 gün içerisinde multifokal dejenere alanlara rastlanılmıştır. Hastalıklı balıkların vücutları siyaha yakın bir renk alır, hastalığı atlatan balıklarda dönerek yüzme gibi sinirsel semptomlar baş gösterebilir [34, 40].

Hastalıklı hayvanlardan alınan örneklere uygulanan real time polimeraz zincir reaksiyonu (RT-PZR) testinden elde edilecek pozitif sonuçlar etkenin varlığını göstermektedir. Enfeksiyondan korunmak amaciyla kontrol protokollerine uyulmalı ve şüpheli kaynaklardan yumurta alınmamaya dikkat edilmelidir [20]. Hastalık, 3285 Sayılı Hayvan Sağlığ1 Zabıtası Kanunu (HSZK) kapsamında 1 Nisan 2004 tarih ve 2004/14 sayılı tebliğinden itibaren ihbarı mecburi balık hastalığı olarak tanımlanmıştır [8].

\section{Sazanların Bahar Viremisi (SBV)}

Avrupa'da kendine son derece geniş bir yayılma alanı bulan etken Rhabdoviridae familyasının Vesikulovirus genusu içerisinde yer almaktadır [1]. Dünya genelindeki sazan balıkları üzerinde yüksek kontagiyöz karakterli ve ciddi enfeksiyona yol açan
SBV virusu OIE'nin 2011 yılında yayımladığg lisetede bildirilmesi gerekli bir patojen olarak rapor edilmiştir [44]. Virus, eter, 1s1 ve aside duyarlıdır [1]. Optimal replikasyon pH'si 7.0-10.0'dur [56]. Su sicaklıklarının $10^{\circ} \mathrm{C}-17^{\circ} \mathrm{C}$ olduğu bahar aylarında ölüm oranı çok daha fazla gözlenirken, enfekte balıkların yüksek sıcaklıklarda ürettiği humoral antikorlar yayılmayı durdurabilir ve bu immunite sayesinde re-enfekte olmaktan korunabilirler [1] SBV virusu, horizontal yolla yayılmaktadır [50].

Ölümcül bir enfeksiyon oluşturan etken, kapillar endotel hücrelere, nefronlara ve hematopoetik yapılara affinite gösterir. Virusun dokular üzerindeki klinik bulguları genel olarak hemorojik oluşumlar ve ödemdir [28]. Balıkların üretim çiftliklerindeki havuzların girişinde yoğunlaşmaları SBV' nin primer belirtilerinden say1labilir. Laterji, dengesiz ve sebepsiz yüzme davranışsal semptomlardır, sudan çıkarılan balığın anal bölgesinden asidik kanlı bir sıv1 gelir [32].

SBV virusu, diğer tatlı su balıklarını da enfekte edebilmesine karşın asıl etkisi sazanlar (C.carpio) üzerinedir. Dış bakıda, deri üzerinde ve gözde hemorajiler, eksophtalmus, abdominal gerginlik gözlenirken, iç bakıda; Peritonitis, ascites, kataral ve hemorajik enteritis, iskelet kaslarında ve yüzme keselerinin çeperlerinde peteşiyel hemorajiler izlenebilmektedir. Etken enfekte balıkların böbrek ve dalaklarından da izole edilmiştir [1, 44].

Enfeksiyonun tanısı klinik bulgular yardımıyla yapılabilir bunun yanı sira indirekt flouresan antikor testi (IFAT) ve Enzym-Linked Immunosorbent Assay (ELISA) testleri de izolasyon ve identifikasyonda kullanılmaktadır [58]. Etkenden korunmak için hastalıkla kontamine balık çiftlikleri karantinaya alınmalı ve bölgedeki balık hareketleri durdurulmalıdır [41]. Ülkemizde, Hayvan Sağlığ 1 Zabıtas Kanununa (HSZK) göre ihbar1 mecburi bir hastaliktır [8].

\section{Yellowtail Asites Virus (YAV) Enfeksiyonu}

Balık, kabuklu ve yumuşakçalarda enfeksiyon meydana getiren bu virus, Birnaviridae familyasının Aquabirnavirus genusundadır. Güneydoğu Asya'daki balıklarda epizootik ülseratif sendroma yol açan viral ajan da bu genus içerisinde yer almaktadır [18]. Virus pH 3-11 arasına, etere ve kloroforma dirençlidir. $56^{\circ} \mathrm{C}$ de 30 dakika boyunca 
etkin kalabilir, replikasyonu idoksuridine ile inhibe edilemez [59]. YAV'in viral replikasyon ve protein sentezinin Japon inci istiridyesinde meydana geldiği elektron mikroskobu ve indirekt florasan antikor testi ile doğrulanmıştır [26]. Bununla birlikte, YAV'ın sebep olduğu hastalıkların baskılanması ve sucul çevrede YAV salgınlarının azaltılması için virusun bir konakçıdan diğerine bulaşma yolunun gün yüzüne çıkarılması gerekmektedir [26].

Genellikle su sicaklıklarının $18^{\circ} \mathrm{C}-25^{\circ} \mathrm{C}$ arasında olduğu Nisan ve Ekim ayları arasında hastal1ğın meydana gelme sıklığı artarken daha sonraki aylarda bir düşüşe geçmektedir. YAV salgını, sekunder enfeksiyon etkenlerinin etkisiyle daha da ağır bir prognoz gösterebilir, bu durum hastalığın teşhisini güçleştirir [25, 49]. Hastalıktan etkilenen yavrularda; anorexia, letarji ve tirbişon şeklinde yüzme hareketleri gözlenir. Abdomen şişkin, intestinal sistem hemorojik ve baş bölgesinde kızarıklıklar görülür. En önemli karakteristik bulgu ise akut kataral enteritistir [11].

İnaktif aşılar kullanılarak hastalıktan korunmaya çalışılmaktadır. Fakat bu tür aşıların doku kültürlerinde veya özel canlı türlerinde üretilmesi için çok miktarda aktif virusa gereksinim duyulmaktadır ki bu da üretim maliyetlerini artırmaktadır. Bununla birlikte attenüe canlı aşılarda balıklar üzerinde infeksiyöz olgu yaratma korkusundan dolayı tercih edilmemektedir. Günümüzde gelişen teknoloji ile birlikte virus proteininden üretilen subunit aşılar inaktif aş1lara göre daha güvenlidirler. Tüm bu sebepler subunit aşı geliştirme çalışmalarını cazip hale getirmektedir [57].

\section{Hirame Rhabdovirus (HIRRV)Enfeksiyonu}

Hirame Rhabdovirus (HIRRV), Rhabdoviridae familyasının Novirhabdovirus genusu içerisinde yer alır [6]. Etken negatif polariteli, tek iplikçikli, lineer morfolojiye sahip bir RNA virusudur [9]. $5^{\circ} \mathrm{C}$ ila $20^{\circ} \mathrm{C}$ arasındaki su sıcaklıklarında replike olabilen Hirame Rhabdovirusun optimum replikasyon sicaklı ̆ $15^{\circ} \mathrm{C}-20^{\circ} \mathrm{C}$ arasındadır. $80 \times 180 \mathrm{~nm}$ boyutlarında ve mermi şeklinde olan virusun, $\mathrm{pH} 3$ 'e, etere ve 1 siya $\left(50^{\circ} \mathrm{C} 2 \mathrm{dk}\right)$ duyarlı olduğu bilinmektedir [35]. Diagnostik testler etkenin Avrupa'da bilinen Novirhabdovirus türleri ile ilişkili olmadığ 1 sonucunu ortaya çıkarmıştır [7]. Etken öncelikli olarak Japon pisi balığını (Paralichthys olivaceus), çipu- ray1 (Spondyliosoma cantharus) ve gökkuşağ1 alabalığını (Oncorhynchus mykiss) enfekte etmektedir [63]. Polonya'da yapılan bir araştırmada [7] tatlı su kültür balıkçılığı yapılan iki çiftliğe hastalığın bulaşmasında Asya'dan gelen ve yem olarak beslemede kullanılan dondurulmuş balıkların yol açtı̆g 1 ortaya konulmuştur. Etkenin, su ve yumurtalar yolu ile taşındığ 1 bilinmektedir [13].

HIRRV enfeksiyonu genellikle gonadlar, yüzgeçler ve iskelet kaslarında yoğunlaşmaktadır [6]. Hasta balıkların genellikle lateral kas sistemlerinde hemorajilere rastlanmakta, dalakta ve hematopoetik dokularda nekroz odakları gözlenmektedir.

Bu semptomlar VHSV ile benzerlik göstermektedir [26].

Nötralizasyon testi ile identifikasyonu mümkün olan etkenden korunmak amacıyla DNA aşısı geliştirme çalışmaları yapılmaktadır $[42,55]$.

\section{Viral Nervous Nekrozis (VNN) Enfeksiyonu}

Viral ensefalopati ve retikülopati olarak da bilinen viral nervous nekrosis enfeksiyonunun etkeni Nodaviridae familyasında Betanodavirus' tur [11]. Çift iplikçikli genoma sahip etken pozitif sarmallı RNA taşır [11]. VNN' nin Amerika ve Afrika kıtaları dışında dünya genelinde de yavru ve larvalarda ciddi hastalıklara yol açtığı bilinmektedir. Günümüzde bu hastalığa 11 familyadan 22 balık türünde rastlanmaktadir [47].

Anaç balıklar virusun en önemli kaynağıdır ve etken, vertikal yol ile yavrulara taşınır $[8,20]$. Retina ve beyin dokularında vakuolleşmeler ile karakterize olan bu hastalık balık populasyonlarında yüksek mortalite oranlarına sebep olmaktadır [43]. Hastalıkta genç balıklarda, ergin balıklara göre daha ciddi lezyonlar meydan gelir [47].

Enfeksiyon sırasında iştah kaybı, anormal yüzüş ve beden renginde koyulaşma, alışılmışın dışında tirbüşon tarzı yüzme gibi klinik bulgular görülebilir. Ayrıca yüzme keselerinde yoğun yangı ve beyinde ciddi konjesyonlar oluşur [11]. Hastalık temel olarak beyin, spinal cord ve retinada gözlemlense de virus balığın gonadlarında veya sindirim kanalinda replike olabilir ve bu replikasyon sonucunda yumurtalar veya larvalar kontamine olabilir [11].

Hastalıktan korunmanın en başarılı yolu yumurtaların dezenfeksiyonudur [28], enfeksiyonun 
tanısında ise hasta balıkların beyin ve retinalarında rastlanılan vakuolleşmeler karakteristik bir özellik taşımaktadır [43]. Bunun yanı sıra enfekte retina ve beyin dokularından yapılan prepararatların elektron mikroskobuyla incelemenmesi ile de virus tanımlanabilir [47]. Enfeksiyona karşı etkin bir tedavi yöntemine literatür araştırmalarında rastlanılamamıştır. Fakat hastalığın başlangıç safhasında enjeksiyon veya immersiyon yolu ile uygulanabilecek aşı çalışmaları hala devam etmektedir [12].

\section{Snakehead Rhabdovirus (SHRV) Enfeksiyonu}

Snakehead Rhabdovirus Rhabdoviridae familyas1nın Novirhabdovirus genusu içerisinde yer almaktadır [3]. Virusun optimum replikasyon sicaklı̆ 1 $15^{\circ} \mathrm{C}$ ile $25^{\circ} \mathrm{C}$ arasindadir. Etken, $37^{\circ} \mathrm{C}$ 'de replikasyonunu gerçekleştirememektedir. Virus, infektivitesini kaybetmeksizin $10^{\circ} \mathrm{C}^{\prime}$ de 30 gün, $8^{\circ} \mathrm{C}$ 'de 10 gün muhafaza edilebilir [38]. Güneydoğu Asya'daki sıcak su balıklarını etkilemektedir [31]. SHRV hakkında Sri-Lanka'da yapılan bir araştırmaya [17] göre hastalığın enfektif alanda yaşama, etkeni barındıran su ile temas ve hastalıklı balıkların popülasyonda bulundurulması ile bulaştığı gösterilmiştir.

Karakteristik olarak nekrotik ülserasyona yol açan SHRV pek çok balık türünde enfeksiyona sebep olmaktadır. Bu balık türlerinin en yaygın olarak bilinenleri; Snakehead (Ophicephalus struatus), yayın balığ1 (Clarias bratachus) ve kum kayabalığ1dir (Oxyeleotis marmoratus) [30]. Süspanse hücre kültüründe $\% 2$ 'lik formalin ile 5 dakika boyunca muamele edilen vürusun \%99.9'u, 30 dakika içinde de tamamı inaktive olmaktadır [17]. Etken elektron mikroskobisi, ELISA ve çapraz nötralizasyon tekniği ile identifiye edilebilir [33].

\section{Channel Catfish Virus (CCV) Enfeksiyonu}

Channel catfish virus (CCV), Herpesviridae familyasının Gammaherpesvirinae alt ailesinin Ictalurivirus genusu içerisinde yer almaktadır [28]. Virusun, \%20'lik eter veya \%5'lik kloroform uygulaması ile enfektivite oranında \%20'lik bir düşüş yaşanır, ayrıca $60^{\circ} \mathrm{C}^{\prime}$ de 1 saatte ve ultraviole 1 ş1ğına maruz kalma durumunda etken inaktive olur [53]. Klinik ve subklinik enfekte balıklar hastalığın rezervuarları olarak kabul edilmektedir. Etkenin, deneysel amaçla enfekte edilen balıkların bulunduğu sudan izole edilmesine rağmen virusun nasıl saçıldığı anlaşılamamıştır, vertikal ve horizontal bulaşma tespit edilmiştir fakat vertikal bulaşmanın mekanizması çözülememiştir [28]. $18^{\circ} \mathrm{C}-20^{\circ} \mathrm{C}$ sıcaklıktaki sularda bulunan 10-30 günlük balıklarda herpesvirus enfeksiyonuna bağlı mortalite oran \%80-90 civarına yaklaşmaktadır. Enfekte balıklarda; deride ve yüzgeçlerde epidermal hiperplazilere, donuklaşmış yüzgeçlere, melanizme rastlanılabilir. Ayrıca nadir de olsa asites gözlemlenmektedir. Asites semptomu gösteren balıkların renal tubulleri dilate olmuştur ve tubular epitelyaları ile karaciğer hücreleri atrofiye haldedir [11].

Etken, nötralizasyon, immunflorasan, ELISA, PZR gibi testler ile teşhis edilebilir [47]. Enfeksiyonu atlatan balıklarda nötralizan antikor seviyesi yüksektir. Bu dönemden sonra virusa ait yapılar tespit edilemese de erişkin balıklarda özellikle üreme dönemi stresiyle birlikte re-enfeksiyonlar oluşabilir [28].

\section{Oncorhynuchus masou Virus(OMV)Enfeksiyonu}

Herpesviridae familyasında bulunan virüse geçici olarak Oncorhynuchus masou virüs (OMV) adı verilmiştir [36]. OMV'nin optimum replikasyon sıcaklığ $15^{\circ} \mathrm{C}$ civarlarıdır. Etken, 1sıya, etere ve aside (pH 3) karşı duyarlıdır. UV ışı̆̆ 1 ile tamamen inaktive olan OMV'nin viral replikasyonu primidin analoglariyla, fosfoasetat ve asiklovir gibi kimyasallarla inhibe edilebilir [64]. OMV'nin konakç1lar1 klinik enfekte ve bir kültürden diğerine gizlice geçiş yapan vahşi balıklar olarak belirlenmiştir. Enfeksiyon dışkı, idrar, seksüel sıvılar ve deri mukusu ile yayılabilmektedir. Su büyük bir abiyotik rol üstlenirken yumurta yüzeylerinin teması da horizontal bulaşmaya sebep olabilmektedir [50]. OMV onkojenik bozukluklarla birlikte deride ülseratif dejenerasyonlara neden olur [28].

Klinik muayenede ödem ve hemorajilerle ilişki halinde ilk olarak sistemik ve çoğunlukla ölümcül enfeksiyonlar şeklinde görülür [50]. Virus endotelyal kan kapillar hücrelerinde ve hematopoetik dokularda enfeksiyon meydana getirir. Bazı vakalarda karaciğerde beyaz odaklanmalara rastlanılabilir [37]. Klinik enfeksiyonu atlatan pek çok balıkta 4 ay sonra ağız kenarlarında, 1 yıl sonra caudal yüzgeçte, operkulumda ve vücudun farklı bölgelerinde neoplaziler meydana gelmektedir [28]. Klinik semptomların incelenmesiyle ve laboratuar analizlerinden 
IFAT ve PZR yöntemi ile etkenin tespit edilmesi mümkündür, korunmada ise formalin ile inaktive edilmiş OMV aşısı kullanmanın yavrular üzerinde çok etkili bir koruma sağladığı bilinmektedir [50].

\section{Salmonid Alphavirus (SAV) Hastalığı}

Etken, Togaviridae familyasının Alphavirus genusu içerisinde yer alır, 55- $65 \mathrm{~nm}$ büyüklüğünde ve zarlı olan SAV tek iplikçikli RNA taşır [51]. Bugün için salmonid balıklarda görülen alphavirusları 6 alt tipe ayırabiliriz $[24,64]$. Bunlardan alt tip 1 ve alt tip 3-6 pankreas hastalığına (PD), alt tip 2 sleeping hastalığına (SD) sebep olmaktadır. SAV-1 ve SAV4 öncelikli olarak deniz Atlantik somonlarından, SAV-3 Norveç'te denizde yetiştirilen gökkuşağ1 alabalıklarından izole edilmiştir [64]. Su sıcaklığının $8^{\circ} \mathrm{C}-15^{\circ} \mathrm{C}$ arası olduğu durumlarda akut halde olan enfeksiyon, su sıcaklığının $8^{\circ} \mathrm{C}$ altına düştüğü sicaklıklarda kronikleşmektedir [64].

Salmonid Alphavirus; enfekte balıklar, kontamine su ve su gereçleri ile bulaşır. Hasta balık etkeni 6-12 hafta boyunca yayabilir ve hatta deniz suyunda 2 yıl boyunca salgınlar gözlenebilir [46], virus deniz suyunda uzun süre enfektivitesini korumaktadır [51]. Salgın sürüde gözlenmeden bir veya iki hafta önce iştahta düşüş yaşanır. Salgın sırasında balık yüzeye yakın, kafesin köşelerinde yüzerken ya da kafesin veya tankın dibinde dinlenirken gözlemlenebilir [51].

Makroskobik değişiklikler farklı olmakla birlikte karşılaşılan en yaygın bulgu sarı mukoid intestinal dokudur. Kimi balıklarda pylorik kesede peteşilere, hemoperikardiyumda ruptura neden olabilir. Ayrıca dolaşım problemlerine işaret olan eksophtalmusla, asitesle veya ödematoz oluşumlarla karşılaşılabilinir. Histopatolojik olarak, pankreas ekzokrininde, iskelet ve kalp kaslarında değişikliklere yol açar [51].

Serum nötralizasyon testi ve real-time PZR tekniği ile teşhisi mümkün olan enfeksiyondan korunmak için [51], stres faktörlerinin azaltılması, canlı balık transferlerinden kaçınılması, balık yetiştiriciliğine uygun malzeme kullanılması, kalifiye personel ile çalışılması gibi önlemler alınmalıdır [51].

\section{Koi Herpesvirus Hastalığı (KHVH)}

Etken, Herpesvirus üstfamilyasının Alloherpesvirus genusunun Cyprinid Herpes Virus-3 (CyHV-3) tü- rüdür. Sekans analizleri CyHP-3 etkenin CyHP-1 ve CyHP-2 etkenleri ile yakın ilişkili olduğunu göstermiştir [41]. Toplu Koi Sazan’1 ölümleri ilk olarak 1998 yılında Amerika Birleşik Devletleri ve İsrail'de rapor edilmesine karşın yapılan örnek analizlerinde 1996 yılından beri Birleşik Krallık' ta doğal yaşamdaki sazanlarda bu etkene rastlanıld1ğ1 bildirilmiştir. Günümüzde ise, Güney Amerika, Kuzey Afrika ve Avustralya hariç dünyanın geri kalanında CyHV-3'e rastlanılmaktadır [58]. CyHV3 enfekte olmuş balık ile direkt temas yoluyla, enfekte balığın vücut sıvıları yolu ile enfekte çamur, su gibi faktörler ile taşınmaktadır. Etken balıklara birincil olarak deriden bulaşır [21]. KHV enfeksiyonu su sicaklıklarının $16^{\circ} \mathrm{C}-25^{\circ} \mathrm{C}$ arası olduğu tipik bahar aylarında görülür ve inkübasyon süresi su sıcaklıklarına bağlı olarak 7-21 gün arasında değişmektedir. Deneysel çalışmalar etkenin, $28^{\circ} \mathrm{C}$ civarı su sıcaklığında mortaliteyi artırdığını ortaya koymuştur. CyHP-3, sıcak sularda soğuk sulara karŞın daha hızlı bir enfeksiyon tablosu oluşturur [21].

Morbidite \%100, mortalite \%80-90 seviyesine sahip [48] ve her yaştan sazanda görülebilen KHV hastalığı balıkların solungaçlarında inflamasyonlara, hiperpilazilere, hematopoetik dokularda ise nekrozlara sebep olabilmektedir [20]. KHV enfeksiyonu sirasinda en fazla etkilenen organlar arasında yüzgeçler, böbrekler ve dalak sayılabilmektedir [48]. Enfeksiyonun tanısı tipik klinik bulgular incelenerek konulabilir. Bununla birlikte histolojik bakıda solungaç epitellerinde büyük hücre proliferasyonlarına rastlanılır. Etken, KF-1 hücre kültürlerine yapılan ekimler sonucunda izole edilse de PZR yöntemi bu yöntemden çok daha etkilidir [54]. Güvenli ve efektif bir aşılama şu an için mevcut olmasa da balıkların korunmasında attenüe aşılar kısmi olarak kullanılabilmektedir. Aşı virusa karşı bir antikor oluşumu sağlamasına rağmen aşının koruma süresi belirsizdir. OIE 2009 çalışmasına göre inaktif KHV içeren lipozom bazlı aşıların ağıdan uygulamaları ile enfeksiyona karşı koruma sağlandığ gözlemlenmiştir [48]. Türkiye'de Hayvan Sağlığı Zabıtası Kanununa (HSZK) göre hastalığın ihbarı mecburidir.

\section{Lenfokist Hastalığı (Lymphocystis Disease, LCD)}

Taksonomik olarak etken, Iridoviridae familyasının Lymphocystivirus genusu içerisinde yer almaktadır 
[4]. Enfeksiyon genellikle kalkan, pisi ve dil balığ1 gibi yassı balıklarda görülmekle birlikte tatlı su levreğinde de gözlenmiştir. Bilinen bulaşma şekli kontamine materyal ve enfekte sular yolu iledir [15]. Lymphocystis virus balıklar üzerinde en kolay belirlenebilen viral etkenlerden biridir. Hastalık balıkların derilerinde büyük hipertrofilerle karakterizedir [62]. Virusla enfekte hücreler normal boyutlarından çok daha büyük boyutlara ulaşabilirler (1mm) [15]. Hastalık deride, solungaçlarda, kuyrukta ve yüzgeçlerde siğil benzeri yapılar oluştuktan sonra spontane bir şekilde iyileşmektedir. LCD virusu tatlı ve tuzlu sulardan nehir ağızlarına kadar pek çok habitatta yaşayan 140'dan fazla balık türünden izole edilmiştir [62].

Lymphocystis tanıs1, klinik olarak tipik büyümüş hücrelerin gözlemlenmesiyle konulabilir [11]. Hastalığın kontrolü için en iyi yol mümkün olan en kısa zamanda çiftliği enfekte balıklardan arındırmak ve çapraz kontaminasyonu önlemektir [4].

\section{Yüzme Kesesi Yangısı (Swim Bladder Inflammation, SBI)}

SBI, sazanların ilkbahar viremisi ve eritrodermatitis ile birlikte enfeksiyöz hidrops kompleksini oluşturan bir hastalıktır [15]. Etken sazanların ilkbahar viremisine yol açan Rhabdoviridae carpio ile aynı serolojik yapıyı taşımaktadır. Bu etken de tıpkı diğer rhabdoviruslarda olduğu gibi mermi benzeri bir morfolojiye sahiptir [23].

Enfeksiyon direkt ve indirekt yolla yayılır, yüzme kesesinde genetik anomaliden kaynaklanan anatomik bozukluk bulunan balıklar hastalığa predispozedir [15].

Genel muayenede karın bölgesinde şişlik, yüzme bozuklukları, reflekslerde yavaşlama, ekzoftalmus ve deride hiperpigmentasyona rastlanır [15]. Nekropsi bulgularında ise, peteşiyel kanamayı takiben hava kesesinin ön ve arka duvarları kalınlaşmıştır. Nekroza bağlı olarak meydana çıkan yangısal reaksiyonlar sonucu peritonitis ile karşılaşılabilir. Hava kesesinin arkasında kanlı sarı bir iltihaplanma oluşur, son dönemlere doğru ise kese işlev göremez hale gelir ve kistik bir duruma geçer. Anüste prolapsus meydana gelir [10]. Enfeksiyonun tanısında klinik ve histopatolojik bulgular ile nekropside elde edilen veriler kullanılabilir, ayrıca günümüzde ge- lişen teknoloji ile birlikte moleküler yöntemlerden faydalanilır [15].

\section{Çiçek Hastalığı (Fish Pox)}

Poxviridae familyasında bulunan ve DNA genomuna sahip etken, sazanlardan elde edilen hücre kültürlerinde kolaylıkla üretilir $[15,58]$. Sporadik seyreden hastalık cyprinid türlerinde yaygın olarak görülmektedir ve mortalitesi çok düşüktür. Virus vücut yüzeyindeki portantrelerden girerek enfeksiyonan sebep olur [15]. Genellikle lokal ve kronik olan lezyonlar epidermal hyperplaziler doğurur. Açık renkli kabarıklar ve lekeler papillomlara sebep olur [58]. Mikroskobik incelemede; vakualizasyon ve multinükleer dev hücreler görülebilir. Nekropside iç organlarda herhangi bir değişikliğe rastlanılmamaktadir. Histopatolojik muayenede dermisin hiperplazisi en önemli bulgulardan biridir [15]. Çiçek hastalığının klinik olarak tanınması mümkünse de diğer tümöral ve paraziter hastalıklarla karıştırılabilmektedir. Bundan dolayı histopatolojik muayene ile hastalığın varlığg doğrulanmalıdır [15]. Mortalitesi düşük olan bu hastalıktan korunmak için genel korunma prensipleri takip edilmelidir [15].

\section{Stomatopapilloma}

Enfeksiyonun etkeni DNA genomu barındıran Papoviridae familyasının Stomatopapilloma virusudur.[15] Karnıbahar hastalığ olarakta bilinen stomatopapilloma ilk olarak 20. Yüzyılda Avrupa' da rapor edilmiştir. Her yaşta ve boyda yılanbalığ 1 enfekte olabilmektedir. Genellikle kafa bölgesinde bening epidermal neoplazilerle karakterize olan bu hastalıkta lezyonlar vücudun diğer bölgelerinde de görülebilmektedir. Papillomlar, fibro-epitelyal yap1dadır, doku proliferasyonlarının sebebi ise tam olarak bilinmemektedir [5].

\section{Turna Balıklarının Kızıl Hastalığı}

Turna balıklarındaki (Exos lucius) bu enfeksiyona, Rhabdoviridae familyasından Vesiculovirus genusundan Pike fry rhabdovirus sebep olmaktadır [39]. Akut bir enfeksiyona sebep olan bu hastalık genç bireylerde hidrosefalus oluştururken yaşlı bireylerde kızıl hastalığına sebep olmaktadır. Etken Avrupa' da geniş bir şekilde yayılmıştır ancak diğer kıtalarda rapor edilmemiştir. Hidrasefalus evresinin klinik bulgularının ilk dönemlerinde laterjiye ve anormal 
yüzmeye rastlanmaktadır, en önemli bulgulardan biri ise hidrasefalusa bağlı olarak eksoftalmusla birlikte seyreden kafanın dorsalinde gözlerin hemen arkasında bir ödem oluşmasıdır. Hemorajik (kızıl) formunda ise abdominal bölgede ve pelvik yüzgeçlerde kırmızı ve şişkin alanlara rastlanmaktadır. Abdominal boşlukta asites oluşur, Etkenin identifikasyonu ELISA, nötralizasyon testi, PZR, IFAT ile mümkündür [46].

\section{Kaynaklar}

1. Ahne W, Björklund HV, Essbauer S, Fijan N, Kurath G, Winton J R, (2002). Spring viremia of carp. Dis. Aquat. Org. 52, 261-272.

2. Albayrak H, Özan E, (2010). Gökkuşağı alabalıklarında (Oncorhnychus mykiss Walbaum,1792) infeksiyöz pankreatik necrosis ve infeksiyöz haemopoetic necrosis virus enfeksiyonlarının varlığının araştırılması. Ankara Üniv. Vet. Fak. Derg. 57, 125-129.

3. Alonso M, Carol H K, Johnson M C, Pressley M, Leong J, (2004). The NV Gene of Snakehead Rhabdovirus (SHRV) Is Not Required for Pathogenesis and a Heterologous Glycoprotein Can Be Incorporated Into The SHRC Envelope. J. Virol. 78, 5875-5887.

4. Alvarez-Pellitero P, Barja J L, Basurco B, Berhat F, Toranzo A E, (2004). Report About Fish Viral Disease, Options Mediterraneennes: Serie B.Etudes et Recherches. 49, 91102.

5. Andor Doszpoly, Zoltán L. Tarján, Róbert Glávits, Tamás Müller, Mária Benkő. (2014). Full genome sequence of a novel circo-like virus detected in an adult European eel Anguilla Anguilla showing signs of cauliflower disease. Dis. Aquat. Org. 109, 107-115.

6. Borzym E, Matras M, Maj J, Sandomierska A, Olesen N J, Eliassen M, Baud M, Talbi C, Bigarre L, (2012). First Detection od Hirame Rhabdovirus (HIRRV) in Europa. 16. Annual Meeting of the National Reference Laboratories for fish Diseases Aarhus/Denmark.

7. Borzym E, Matras M, Maj-Paluch J, Baud M, De Boisseson C, Talbi C, Olesen N, Bigarre L, (2014). First Isolation of Hirame Rhabdovirus from Freshwater Fish in Europa. J. Fish. Dis. 37, 423-430.

8. Buket Ö.Ö, (2016). Türkiye'de Ihbarl Mecburi Balı Hastalıkları. Veteriner Kontrol ve Araştırma Enstitüsü Bornova/İzmir.

9. Caiping C, Hirono I, Aoki T, (2003). In Vitro Inhibition of Fish Rhabdoviruses by Japanese Flounder, Paralichtys olivaceus Mx. Virology. 317, 373-378.

10. Candan A, (2002). First report on the diagnosis of infectious pancreatic necrosis (IPN) based on reverse transcription polymerase chain reaction (RT-PCR) in Turkey. Bull. Eur. Assoc. Fish Pathol. 22, 45-48.

11. Castric J, (1997). Viral Diseases in Fish Mariculture, Eur. Assoc. Fish Pathol. 17(6), 220.
12. Chiu-li C, Han-You Lin J, Chen M, Yang H, (2007). An oral nervous necrosis virus vaccine that induces protective immunity in larvae of grouper (Epinephelus coioides). Aquaculture. 268, 265-273.

13. Dietzgen RG, Kuzmin I, (2012). Rhabdoviruses: Molecular Taxonomy, Evolation, Genomics, Ecology, Host-Vector Interactions, Cytopathology and Control. British Library Catologuing in Publication Data. p. 18.

14. Dixon P, Paley R, Alegria-Moran R, Oidtmann B. (2016). Epidemiological characteristic of infectious hematopoietic necrosis virus (IHNV) : a review. Vet. Res. 47, 1-26.

15.Erer H, (1995). Balık Hastalıkları, Selçuk Üniversitesi Veteriner Fakültesi Yayın Ünitesi. Konya, Yayın No:994/008, p. 54-67.

16. FAO, (2015) Global Aquaculture Production statistics database updated to 2013 Summary information In March 2015 (www.fao.org/fishery/statistics/global-aquacultureproduction/query/en). Erişim Tarihi: 21.12.2015.

17. Frerichs GN, (1990). Efficacy of Chemical Disinfectants Against Snakehead Rhabdovirus. J. Apll. Ichthyol. 6, 117 123.

18. Gn Frerichs, (1995). Viruses Associated with Epizootic Ulcerative Syndrome (EUS) of Fish in South-east Asia. BMC Vet. Res. 26(5-6), 449-454.

19. Gürçay M, Turan T, Parmaksız A, (2013). Türkiye'de kültürü yapılan gökkuşağı alabalıklarında (Oncorhynchus mykiss Walbaum,1792) infeksiyöz Pankreatik Nekrozis Virus varlığının tespiti üzerine bir araştırma. Kafkas Univ Vet Fak Derg. 19(1), 141-146.

20. Hanson L, Dishon A, Kotler M, (2011). Herpesvirus that Infect Fish. Viruses. 3, 2160-2191/V 3112160.

21. Hartmann KH, Yanong PER, Pounder DB, Petty BD, Francis-Floyd R, Riggs AC, Waltzek TB, (2004). Koi Herpes Virus Disease (KHVD). VM-149, University of Florida.

22. Hawley L, Garver K, (2008). Stability of viral hemorrhagic septicemia virus (VHSV) in freshwater and seawater at various tempetures. Dis. Aquat. Org. 82, 171-178.

23. Hill BJ, (1975). Phsico-chemical and Serological Characterization of Five Rhabdovirus Infecting Fish. J Gen Virol. 27, 369-378.

24. Hodneland K, (2006). Salmonid Alphavirus (SAV) Genetic characterisation of a new sub type, $S A V-3$, and implementation of a novel diagnostic method. University of Bergen, Norway p. 27-28.

25.Inaba M, Kimura T, Kikukawa R, Iwasaki M, Nose M, Suzuki S, (2007). Annual dynamics of marine birnavirus (MABV) in cultured Japanese flounder Paralichthys olivaceus and sea water. Fisheries Sci. 73, 615-622.

26.Isshiki T, Nagano T, Suzuki S, (2001). Infectivity of Aquabirnavirus Strains to Various Marina Fish Species. Dis. Aquat. Org. 46, 109-114.

27. Isshiki T, Nishiziwa T, Kobayshi T, Nagano T, Miyazahi T, (2001). An Outbreak of VHVS (Viral Hemorrhagic Septisemia Virus) Infecion in Farmed Japanese Flounder Paralichthys olivaceus in Japan. Dis. Aquat. Org. 47, 8799. 
28. Işıdan H, (2006). Önemli bazı viral balık hastalıkları-1. SÜMAE Yunus Araştırma Bülteni. 6, 10-13.

30. Işıdan H, Bolat Y, Özdarendeli A, Albayrak H, Kutlu İ,Türe M, (2010). Karadeniz Bölgesinde Kültürü Yapılan Ve Doğal Balıklardan Viral Hemorajik Septisemi Virüs (VHSV) İzolasyon Çalışmaları Ve Elde Edilecek İzolatların Patojenitesini Belirleyen Genetik Yapı Üzerine Çalışmalar. Proje Sonuç Raporu Kitabı. Su Ürünleri Merkez Araştırma Enstitüsü Müdürlüğü.

31. Johnson MC, Maxwell JM, Loh PC, Leong JC, (1995). Moleculer characterization of the glycoproteins from two warm water rhabdoviruses.Snakehead rhabdovirus(SHVR) and rhabdovirus of penaeid shrimp (RPS)/Spring viremia of carp virus (SVCV). Virus Res. 64, 95-106.

32. Johnson MC, Simon BE, Kim CH, Leong JC, (2000). Production of Recombinant Snakehead Rhabdovirus: The $N V$ protein is not required for viral replication. J. Virol. 74, 2343-2350.

33. Kalayc1 G, Özkan B, (2016). Ihbari Mecburi Viral Balık Hastalıkları. Bornova Veteriner Kontrol ve Araştırma Enstitüsü Müdürlüğü. http://www.bornovavet.gov.tr/pdf/ ihbarimecburi.pdf, Erişim tarihi: 28.04.2016.

34. Kasonchandra J, Engelking HM, Lannan CN, Rohovec JS, Fryer JL, (1992). Characteristics of three rhabdoviruses from snakehead rhabdovirus Ophicephalus striatus. Dis. Aquat. Org. 13, 89-94.

35. Kim R, Faisal M, (2011). Emergence and resurgence of the viral hemorrhagic septicemia virus (Novirhabdovirus , Rhabdoviridae,Mononegavirales). Journal of Advanced Research. 2, 9-23.

36. Kimura T, Yoshimizu M, Gorie S, (1986). A New Rhabdovirus Isolated in Japan from Cultured Hirame (Japanese Flounder) Paralichthys olivaceus and ayu Plecoglossus altivelis. Dis. Aquat. Org. 1, 209-217.

37. Kimura T, Yoshimizu M, Tanaka M, Sannohe H, (1981). Studies on a New Virus (OMV) from Oncorhynuchus masou Charateristics and Pathogenicity. Fish Pathol. 15(3/4), 143-147.

38. Kubilay A, Nurcan N, (2009). Gökkuşă̆ alabalı̆̆ (Oncorhynchus mykiss)'nda İnfeksiyöz Pankreatik Nekrosis (IPN) Virusu ve Teşhis Metotları. Süleyman Demirel Üniversitesi Fen Bilimleri Enstitüsü. Yüksek Lisans Tezi, Isparta.

39. Lio-po GD, Traxler GS, Albright LJ, Leano EM, (2000). Characterization of a Virus Obtained from Snakeheads Ophicephalus striatus with Epizootic Ulcerativ Syndrome (EUS) in Philipinnes. Dis. Aquat. Org. 43, 191-198.

40. M Vicenova, S Reschova, D Pokorova, J Hulova, T Vesely, (2011). First detection of pike fry-like rhabdovirus in barbel and spring viraemia of carp virus in sturgeon and pike in aquaculture in the Czech Republic. Dis. Aquat. Org. 95, $87-95$.

41. Meyer F, Warren J, Garey T, (1983). A guide of integrated fish health management in the great lake basin. Bullock G. L. eds. Special publication No.83-2, Great Lakes Fishery Commision 1451 Green Road Ann Harbor, Michigan 48105. p. $170-176$.
42. Michel B, Fourner G, Lieffrig F, Costes B, Vanderplasschen A, (2010). Cyprinid Herpesvirus 3. Emerging İnfect. Dis. $16,1835-1843$.

43. Murphy FA, Gibbs EPJ, Horzinek MC, Studdert MJ, (1999). Veterinary Virology. 3. Edition. Academic Press. p. 442.

44. Nguyen HD, Mekuchi T, Imura K, Nakui T, Nishizawa T, Murago K, (1994). Occurence of Viral Nervous Necrosis(VNN) in Hatchery-Reared Juvenile Japanese Flounder Paralichthys olivaceus. Fisheries Sci. 60, 551554.

45. Nicholas B. D. Phelps, Aníbal G. Armién, Sunil K. Mor, Sagar M. Goyal, Janet V. Warg, R. Bhagyam, Monahan T. (2012). Spring Viremia of Carp Virus in Minnehaha Creek, Minnesota. J. Aquat. Anim. Health. 24, 232-237

46. Nishizawa T, Savaş H, Işıdan H, Üstündağ C, Ivamoto H, Yoshimizu M, (2006). Genotyping and pathogenicity of viral hemorrhagic saptisemia virus from free-living turbot (psetta maxima) in aTurkish coastal area of the black sea. Appl Environ Microbiol. 72, 2373-2378.

47. Noga JE, (2010). Fish disease: diagnosis and treatment, Second Edition-2. Wiley-Blackwell p. 294.

48. OIE Fish Diseases Commision, (2000). Diagnostic Manual for Aquatic Animal Diseases Third Edition. Office İnternational Des Epizooties. p. 104. Erişim tarihi: 28.04.2016.

49. OIE, (2009). Manuel of Diagnostic Tests for Aquatic Animals. Chapter 2.3.6, Erişim tarihi: 06.04.2016.

50. OIE, (2009). Spring Viramia of Carp. Manuel of Diagnostic Tests for Aquatic Animals. Chapter 2.3.8, Erişim tarihi: 06.04.2016.

51. OIE, (2012). Oncorhynchus masou Virus Disease. Manuel of Diagnostic Tests for Aquatic Animal., Chapter 2.3.10, Erişim tarihi: 18.04.2016.

52. OIE, (2013). Aquatic Animal Disease Cards. 12 rue de prony 75017, Paris/FRANCE, Erişim tarihi: 12.04.2016.

53. Özer S, (2004). Viral hemorojik septisemi virusu ve infeksiyöz hematopoetik nekrosis virusunun moleküler epidemiyolojisi. Ege Üniversitesi Su Ürünleri Dergisi. 21(1-2), 173 179.

54. Plumb JA, (1986). Channel Catfish Virus Disease. Erişim adresi: http://digitalcommons.unl.edu/usfwspubs/144, Erişim tarihi: 06.11.2016.

55. Pokorova D, Vesely T, Prackova V, Reshova S, Hulova J, (2005). Current knowledge on koi herpesvirus (KHV): a review. Vet. Med. Czech. 50, 139-147.

56. Roberts RJ (2012). Fish Pathology Fourth Edition, WileyBlackwell. p. 279.

57. Sanders EG, DVM, Batts NW, Winton JR, (2003). Susceptibility of zebrafish (Danio reiro) to a model pathogen, Spring Viremia of Carp Virus. Comparative Medicine by the American Association for Laboratory Animal Science. 53, 514-521.

58. Sato H, Nakajima K, Maeno Y, Kamaishi T, Kamata T, Mori H, Kamei K, Takano R, Kudo K, Hara S, (2000). Expression of YAV Proteins and Vaccination Against Viral 
Ascites Among Cultured Juvenile Yellowtail. Bioscience, Biotechnology, Biochemistry. 64, 1494-1499.

59. Smith KM, Lauffer MA, (1966). Advances in Virus Research, Academic Press İnc., 12th Edition, 111 Fifth Avenue, NY 10003. p. 83-84.

60. Sorimachi M, Huna T, (1985). Characteristic and Pathogenicity of a Virus Isolated from Yellowtail fingerlings showing ascites. J. Fish Pathol. 19, 231-238.

61. Thompson TM, Batts WN, Faisal M, Bowser P, Casey JW, Phillips K, Garver KA, Winton J, Kurath G. (2011). Emergence of Viral hemorrhagic septicemia virus in the North American Great Lakes region is associated with low viral genetic diversity. Dis. Aquat. Org. 96, 29-43.
62. Tekelioğlu N, Kumlu M,Yanar M, Erçen Z, (2007). Türkiye'de Su Ürünleri Üretimi Sektörünün Durumu ve Sorunları. Ulusal Su Günleri, 16-18 Mayis, Antalya.

63. Woo PTK, Leatherland FJ, Bruno DW, eds., (2011). Fish Diseases and Disorders Volume 3: Viral,Bacterial and Fungal Infections 2nd Edition. CAB İnternational. p. 281.

64. Yingjie S, Min Z, Hong L, Zhiqin Y, Xiaocong Z, Zhe W. (2011). Analysis and characterization of the complete genomic sequence of the Chinese strain of hirame rhabdovirus.J. Fish Dis. 34, 167-171.

65. Yin-Ka L, (2004). Current Trend in the Study of Bacterial and Viral Fish and Shrimp Diseases. Leung Ka Yin eds. World Scientific Publishing Co. Pte. Ltd. p. 70-71. 